TARNOWSKIE STUDIA TEOLOGICZNE 36 (2017) NR 1, S. 37-57

http://dx.doi.org/10.15633/tst.2323

Bogumił Chmiel $^{1}$

PODEGRODZIE

\title{
Zanikanie świętości. Natura i źródła procesu desakralizacji w kulturze Zachodu
}

Niniejszy artykuł opisuje zasadniczy aspekt zjawiska określanego mianem desakralizacji/ sekularyzacji kultury zachodniej oraz charakteryzuje główny czynnik, który ten proces zainicjował. Mając na uwadze złożoność omawianego problemu oraz mnogość perspektyw, z jakich jest on analizowany (socjologiczna, psychologiczna, ekonomiczna), należy podkreślić, że poniższe rozważania filozoficzne bazują na koncepcji religii (sacrum) i kultury inspirowanej myślą tradycjonalizmu integralnego. Jako podstawa wszystkich analiz została ona wyjaśniona w pierwszej części artykułu. Drugą część poświęcono krytycznej refleksji nad naturą desakralizacji.

Proces desakralizacji kultury Zachodu uznawany jest jako fakt przez wszystkich badaczy, niezależnie od właściwej im perspektywy metodologicznej, światopoglądu i związanej z tym oceny tego zjawiska. Nieco mniej uwagi poświęca się temu, co można określić jako „resakralizację”, a więc procesowi „przywracania” świętości tym sferom życia, które zdawałoby się już dawno utraciły swoją sakralną naturę ${ }^{2}$. Niezależnie jednak od pojawia-

1 Bogumił Chmiel - absolwent teologii na Katolickim Uniwersytecie Lubelskim Jana Pawła II i filozofii na Uniwersytecie Marii Curie-Skłodowskiej. Doktor filozofii na podstawie pracy o dziejach filozofii wieczystej. Interesuje się historią i filozofią religii.

2 Przykładem takiego zjawiska jest „renesans” rodzimowierstwa we współczesnej Europie, którego integralnym elementem jest „sakralizacja” całej rzeczywistości. Kwestią otwartą pozostaje pytanie, czy współczesne rodzimowierstwo jest odtworzeniem wiary panującej wśród wspólnot europejskich przed chrystianizacją, czy raczej tworem nowoczesnej kultury nawiązującym jedynie do kultur przedchrześcijańskich. Por. K. Biliński, Refleksje o podstawach ruchów neopogańskich, w: „Państwo i Społeczeństwo” 8 (2008) nr 4, s. 55-64. Innym przykładem powrotu do sacrum jest niesłabnące zainteresowanie kulturami Wschodu. 
jących się symptomów powrotu do sacrum, całościowe spojrzenie na kulturę Zachodu jednoznacznie wskazuje na proces zanikania wpływu religii na poszczególne sfery życia indywidualnego i wspólnotowego określanego mianem desakralizacji/laicyzacji ${ }^{3}$. Znakomita większość analiz opisujących to zjawisko opiera się na rozróżnieniu pomiędzy sacrum (utożsamianym $\mathrm{z}$ religią) i profanum (identyfikowanym z kulturą laicką), które - jako narzędzie metodologiczne - traktowane jest często bez głębszego namysłu, na zasadzie oczywistości. Tymczasem kwestia natury sacrum oraz jego stosunku do pozostałych elementów kultury wydaje się zasadnicza nie tylko w przypadku refleksji nad istotą religii, ale również nad zjawiskiem desakralizacji. Samo to rozróżnienie wymaga zatem uważnego namysłu, stanowiąc horyzont dociekań dotyczących fenomenu desakralizacji.

\section{Sacrum}

Podejmując kwestię natury sacrum, warto zacząć od tego, że dla większości współczesnych ludzi (w tym naukowców zajmujących się zawodowo religią i kulturą) rozróżnienie na sferę sacrum i profanum jawi się jako oczywiste. Przekonanie, wedle którego miejsca kultu, artefakty liturgiczne i święte księgi należą do pierwszej, a instytucje polityczne, ekonomiczne i zdrowotne do drugiej dziedziny wydaje się oczywiste i niejako zawarte w samym języku; skoro mówimy i myślimy o tych dwóch domenach jako niezależnych, to znaczy, że istnieją one w taki właśnie sposób - jako względnie autonomiczne rzeczywistości. Proces sekularyzacji polegałby zatem, najogólniej rzecz ujmując, na dziejowym przechodzeniu/przenoszeniu przedmiotów, zachowań, norm i instytucji ze sfery sakralnej do sfery profańskiej. Co więcej, zgodnie z opinią wielu socjologów, psychologów i filozofów ten proces ma rzekomo poznawczy charakter - jest odkrywaniem, że rzeczywistość, której przypisywano własność świętości/nadprzyrodzoności, faktycznie tej cechy nie posiada. Tym samym, zarówno w wymiarze indywidualnym, jak i społecznym, desakralizacja pojęta jako „odczarowanie” świata staje się głównym faktorem „dojrzewania” człowieka, i to dojrzewaniem w dwojakim sensie. Po pierwsze, w aspekcie epistemologicznym - ludzkość stopniowo „dostrzega” prawdziwą naturę bytu, pozbywając się metafizycznych złudzeń. Po drugie, uwolniona od pozornej zależności względem woli bogów, bierze

3 Por. A. Giddens, Sociology, Polity Press, 2001, s. 485-487. 
moralną odpowiedzialność za swój własny los - dostrzega siebie jako jedyny podmiot i sprawcę dziejów ${ }^{4}$.

Koncepcja sacrum jako zasadniczej kategorii charakteryzującej istotę religii pojawiła się w XIX wieku, a w Xx zyskała rozgłos i poczesne miejsce dzięki publikacji Rudolfa Otto Świętość. Sam Otto w swojej pracy nie poddaje dogłębnej analizie różnicy między świętością a sferą profanum, jednak taka opozycja stanowi swoiste „tło” jego rozważań. Jak wiadomo, głównym terminem, jakim posługuje się niemiecki religioznawca celem oddania istoty doświadczenia religijnego jest numinosum. Popularny termin „świętość” zyskał, w jego opinii, nazbyt moralny charakter, podczas gdy idea numinosum oddaje tę „nadwyżkę”, która decyduje o specyfice doświadczenia religijnego ${ }^{5}$. Zdaniem Otto doświadczenie religijne ma charakter pierwotny - nie poddaje się redukcji do innego (bardziej elementarnego) przeżycia, i wyjątkowy - język nie jest w stanie oddać jego treści, lecz jedynie ją przybliżać. ${ }^{6}$. Wskazując na pojęcia, które (cały czas na zasadzie analogii) wyrażają istotę świętości, Otto podkreśla, że rzeczywistość, która za nią stoi jawi się jako coś absolutnie różnego od „reszty” świata. Tak jak religijna groza (tremendum) różni się od „świeckiego” strachu, a tajemnica (mysterium) od rozwiązywalnej zagadki, tak przedmiot, który wywołuje doświadczenie numinosum, jest ze swej istoty „całkiem inny”, niż pozostałe przedmioty wzbudzające „świecki” strach, zaciekawienie, zachwyt czy obdarzone, choćby i ogromną, ale ziemską, mocą ${ }^{7}$ Takie rozróżnienie postuluje, na zasadzie implicite przyjętego założenia nabierającego charakteru oczywistości, istnienie rzeczywistości świeckiej - w opozycji do której zaznacza się i wyodrębnia wszystko, co sakralne. Na kulturową sferę profanum składa się zatem wszystko to, co jako pozbawione cechy sacrum - niewyrażające, ani niewywołujące przeżycia numinosum - stanowi przestrzeń i treść

4 Takie idee stanowiły trzon oświeceniowej historiozofii, której korzenie - jak postaram się wykazać poniżej - sięgają w przypadku Europy początków filozofii greckiej. Współczesne zwątpienie w duchowy postęp ludzkości (implikowany przez taką perspektywę i wyrażoną dobitnie w myśli Comte’a, Kanta, Hegla i Marksa) idzie w parze ze wspomnianym powyżej „powrotem do religii”, pojmowanym przez zwolenników myśli oświecenia jako obskurantyzm i irracjonalizm.

5 Por. R. Otto, Świętość. Elementy irracjonalne w pojęciu bóstwa i ich stosunek do elementów racjonalnych, przeł. B. Kupis, Warszawa 1999, s. 9-10.

6 Por. R. Otto, Świętosść..., s. 15, 46.

7 Por. R. Otto, Świętość..., s. 33-35. 
„Zwykłych” doświadczeń człowieka ${ }^{8}$. Pozwalając sobie na pewne uogólnienie, można stwierdzić, że w myśli Otto doświadczenie numinosum to moment, w którym absolutnie transcendentna boskość „prześwituje” w świeckiej, asakralnej doczesności.

Należy podkreślić, że źródła przekonania o zasadniczej różnicy między przestrzenią sakralną, w której manifestuje się boskość, a świecką „resztą” świata nie należy upatrywać w poglądach niemieckiego religioznawcy, ani nawet w myśli oświecenia, z której Otto obficie czerpie, chociażby poprzez częste nawiązania do Kanta. Wizja świętości zaprezentowana w jego pracy jest głęboko zakorzeniona w myśli protestanckiej akcentującej przepaść między porządkiem doczesnym i boskim, królestwem niebieskim i państwem ziemskim, nadprzyrodzoną łaską i zepsutą naturą, prerogatywami władzy świeckiej i duchownej. Perspektywa protestancka $\mathrm{z}$ kolei nie powstała w kulturowej „próżni”, ale była efektem renesansowego rozczarowania „zeświecczoną" teologią scholastyczną i instytucjonalizmem Kościoła rzymskiego. Zamiast racjonalizmu mętnych, sofistycznych i bezcelowych dociekań filozoficznych zwolennicy chrześcijańskiego odrodzenia proponowali powrót do prostoty i głębi „czystej” wiary pierwszych chrześcijan opartej na autorytecie Ewangelii, mistycznym doświadczeniu łaski i prostocie życia9 Oczywiście taki „powrót” zakładał już opozycję względem ówczesnego „zepsutego" (świeckiego) świata ${ }^{10}$. Jednocześnie polityczne zaangażowanie Kościoła generujące napięcia na linii Państwo Kościelne - cesarstwo, początki świadomości narodowej i związane z tym dążenia polityczne doprowadziły

${ }^{8}$ Takie rozróżnienie suponuje głęboką różnicę między sakralnym a świeckim doświadczeniem - tylko w drugim pojawiają się elementy numinosum. Przeżycia, podobnie jak świat, rozpadają się na dwie sfery: wyjątkowe doświadczenia sacrum i codzienną świadomość profanum.

9 Por. E. Gilson, Jedność doświadczenia filozoficznego, Warszawa 1968, s. 70. Popularność, jaką w Xv i XVI wieku zyskały koncepcja poznania intuicyjnego i teologia apofatyczna reprezentowana m.in. przez Mikołaja z Kuzy i Marsilia Ficina odzwierciedla ówczesną tendencję do doświadczalnego ujęcia prawd wiary.

${ }^{10}$ Ucieczka ze złego świata w wyizolowaną boską sferę (którą zdaniem Husa i Wiklifa miał uosabiać niezależny od władzy świeckiej Kościół) była tylko jedną stroną medalu. Drugą stanowiło renesansowe dowartościowanie życia doczesnego i związanych z nim obowiązków. Por. S. Swieżawski, Między średniowieczem a czasami nowymi. Sylwetki myślicieli XV wieku, Warszawa 1985, s. 120-121. W obu przypadkach rozdział na sfery sacrum i profanum jest już założony, różnica polega jedynie na sposobie, w jaki jednostka i społeczność pragnie realizować swoje zbawienie. Niezależnie jednak, jaką drogę się wybierze, opiera się już ona na omawianym rozróżnieniu i je legitymizuje. 
do wzmocnienia tendencji pojawiających się już w późnym średniowieczu, do autonomizacji władzy świeckiej. Proces ten zakładał (na zasadzie niewyeksplikowanej wizji), a zarazem kształtował nowożytne odróżnienie porządku profanum i sacrum oraz zaliczenie władzy świeckiej do drugiej dziedziny ${ }^{11}$. Także zarzuty reformatorów pokroju Wiklifa i Husa, a potem Lutra domagające się „oczyszczenia” chrześcijaństwa w duchu ewangelicznym wpisały się w postulowany schemat - poszukiwania, czy wręcz kształtowania (wszak to ludzie z Bożą pomocą mieli dokonać tych zmian) sfery, w której każdy człowiek może doświadczyć świętości obcej codziennemu, profańskiemu światu. W sytuacji gdy dana instytucja (Kościół) bądź człowiek (papież, grzeszni duchowni) nie spełniali wymagań moralnych stawianych tej enklawie sacrum, musieli być z niej wykluczeni do przestrzeni profanum. Wszystkie przytoczone przykłady ilustrują tendencję, która zaczyna coraz mocniej oddziaływać w epoce renesansu, a mianowicie ideę (stanowiącą swoiste tło poszczególnych koncepcji politycznych, teologicznych i filozoficznych) głębokiej różnicy między porządkiem sakralnym i świeckim. Kwestia, jakie instytucje należy zaliczyć do której dziedziny, jest drugorzędna - istotna jest wizja świata, w którym istnieje względnie autonomiczna sfera, rządząca się ludzkimi zasadami, różna od praw, artefaktów, instytucji, osób i rytuałów nacechowanych świętością (tj. wyrażających, a zarazem wyzwalających określone stany duchowe).

${ }^{11}$ Por. S. Swieżawski, Eklezjologia późnośredniowieczna na rozdrożu, Kraków 1990, s. 103-110. Oczywiście przedstawiona wizja jest bardzo uproszczona, bowiem koncepcji relacji między władzą świecką a duchową było wiele, część z nich zachowywała sakralny charakter władzy „świeckiej”, widząc w niej obrońcę czy egzekutora boskich prerogatyw złożonych w instytucji Kościoła. Rzecz jednak w tym, że to właśnie w renesansie coraz głośniej zaczęła rozbrzmiewać idea, wedle której państwo i władza cesarska, królewska itd. należą do porządku różnego od sfery sacrum „zamkniętej” w Kościele - jego instytucjach i osobach. To z kolei suponuje, że w umysłach ludzi pojawiła się idea sfery niezależnej od religii, w której „umieszczono” potestas władców ziemskich. Warto podkreślić, że świat polityki i władzy doczesnej nie jest przedstawiany jako demoniczny, wojujący z Kościołem - w takim przypadku również ta sfera miałaby charakter sakralny - ale jako neutralny. W myśli Lutra królestwo Boże nie jest z tego świata, więc „ten” świat winien cieszyć się autonomią „rzeczy świeckich”. Por. S. Swieżawski, Eklezjologia..., s. 106 


\section{Pierwotny brak rozróżnienia na sfery sacrum i profanum}

Dotychczasowe rozważania szkicują kontekst dla wykazania, że wizja świata podzielonego na sfery sacrum i profanum nie ma charakteru pierwotnego i stanowi skutek zmiany w postrzeganiu rzeczywistości. Próbując jednak zrekonstruować ów „pierwotny” światopogląd, z którego wyodrębnił się (skrystalizowany w myśli Otto) punkt widzenia, natrafiamy na szereg problemów. Przede wszystkim, jak daleko musimy sięgnąć, żeby móc mówić o „pierwotnej” wizji świata? Czy musimy się cofnąć do epoki paleolitu i interpretacji wykopalisk archeologicznych czy wystarczą najstarsze świadectwa pisane? Po drugie, czy wskazując na świadectwa potwierdzające sugerowaną zmianę, nie absolutyzujemy wybranej tradycji odpowiadającej proponowanej wizji historii? Innymi słowy: w jakiej mierze wybrane przykłady mogą być uznane za reprezentatywne dla „pierwotnego” światopoglądu. Pewnych intuicji w rozwiązaniu tych problemów można, w moim przekonaniu, doszukać się w analizach Mircei Eliadego, który stwierdza: „jest całkiem pewne, że wszystko to, czego człowiek się dotknął, co odczuł, napotkał lub pokochał, mogło się stać hierofanią" ${ }^{12}$. Takie stwierdzenie nie do końca oddaje jednak proponowane stanowisko, zwłaszcza że na kolejnej stronie przywołanej pracy rumuński religioznawca dodaje: „Chcemy tu uwydatnić fakt, że hierofania zakłada jakiś wybór, wyraźne oddzielenie przedmiotu hierofanicznego od otaczającej go reszty. Ta reszta zawsze pozostaje, nawet wtedy, kiedy przedmiotem hierofanicznym staje się obszar tak olbrzymi jak niebo, krajobraz rodzinny lub «ojczyzna». Oddzielenie przedmiotu hierofanicznego jest w każdym bądź razie oddzieleniem przynajmniej od niego samego, ponieważ przedmiot ten staje się hierofanią dopiero wtedy, gdy przestaje być zwykłym przedmiotem świeckim i przybiera nowe «wymiary», wymiary sakralności”' ${ }^{\prime 3}$. Przytoczony cytat można rozumieć w sposób sytuujący myśl Eliadego w takiej perspektywie, jaka przyświecała analizom Otto - człowiek, żyjąc w przestrzeni profanum, napotyka przedmioty sakralne (objawiające numinosum), które - w strumieniu codziennych, profańskich zdarzeń - pozwalają chwilowo opuścić naturalny, „świecki” stan i doświadczyć świata „nadprzyrodzonego”. Można jednak uznać go za świadectwo myśli wyrażonej wprost w innej pracy Eliadego Szamanizm i archaiczne techniki ekstazy: „dla

\footnotetext{
${ }^{12}$ M. Eliade, Traktat o historii religii, Warszawa 1966, s. 18.

${ }_{13}$ M. Eliade, Traktat o historii religii, s. 19.
} 
ludzi «prymitywnych» w ogóle nie ma wyraźnej różnicy między «naturalnym» a "nadnaturalnym», między przedmiotem empirycznym a symbolem. Jakiś przedmiot staje się «sobą» (to znaczy nośnikiem jakiejś wartości) wtedy, gdy uczestniczy w jakimś «symbolu»; jakiś akt nabiera znaczenia o tyle, o ile powtarza archetyp itd." ${ }^{14}$. Aby przytoczony cytat właściwie zrozumieć, należy zacząć od stwierdzenia, że nie postuluje on poglądu, wedle którego dla człowieka „pierwotnego” każdy, nawet najbardziej prozaiczny przedmiot (gałązka, kamień) miał z konieczności znaczenie „sakralne” i „nadprzyrodzone”. Obie te kategorie mogą bowiem funkcjonować jedynie jako człon opozycji względem tego, co „świeckie” i „naturalne” - powoływanie się na jedną $\mathrm{z}$ tych kategorii implikuje drugą. W ten sposób tworzą one już swoistą perspektywę rozumienia religii i kultury. Mentalność „pierwotna” natomiast nie zna takiego przeciwstawienia - każdy przedmiot jawi się jej jako integralny element całości rzeczywistości, która - właśnie jako zintegrowane uniwersum, a nie luźny „zbiór” bytów - symbolizuje (a więc zarazem wskazuje „poza” siebie, jak i zawiera „w sobie”) boskość, która istniejąc „poza” światem, jednocześnie jest „w nim” obecna.

Wyjaśniając powyższą tezę, trzeba zacząć od tego, że jej potwierdzenie nie wymaga wyliczania wszystkich obecnie „świeckich” przedmiotów, działań i tworów kultury, którym dawniej przysługiwała wartość sakralna. Nie chodzi bowiem o konkretne przedmioty czy czynności, które faktycznie mogły być postrzegane bez ich hierofanijnego odniesienia, ale o całość rzeczywistości, na którą się owe przedmioty składały i w której naturze uczestniczyły ${ }^{15}$. Jeśli uda się wykazać, że rzeczywistości pojętej jako uniwersum pierwotnie przysługiwał status metafizyczny pozbawiony ostrego rozróżnienia na sacrum i profanum, to uzasadnienie znajdzie również teza, wedle której żaden przedmiot ani działanie nie miały pierwotnie „Czysto” świeckiego lub sakralnego charakteru. Można wtedy będzie stwierdzić, że to rozróżnienie pojawiło się już jako efekt desakralizacji świata; umysł, który uznał, że świat pojęty jako całość nie odsyła do boskości ani jej w sobie nie zawiera, zaczął poszukiwać jej „śladów” skoncentrowanych w poszczególnych przedmiotach

${ }^{14}$ M. Eliade, Szamanizm i archaiczne techniki ekstazy, przeł. K. Kocjan, Warszawa 2011, S. 210.

${ }^{15}$ Poza tym takie wyliczenie, choćby wyjątkowo długie, nadal nie wykazuje nieadekwatności podziału na sacrum i profanum, lecz dowodzi jedynie, że do sfery sakralnej należało bardzo dużo przedmiotów. 
i działaniach wywołujących intensywne przeżycia. Należy dodać, że proponowany pogląd nie podaje w wątpliwość wyjątkowej wartości określonych przedmiotów, miejsc i aktów, w których boskość przejawia się w sposób wyjątkowy. Neguje jednak przeciwstawienie im „neutralnej” sfery świeckiej, wskazując na wszechświat przeniknięty (w różnym stopniu) boską siłą, w którym - niczym w kosmicznym „tle" - coraz to nowe artefakty, miejsca i działania zyskują wyjątkową hierofanijną moc.

Idea, która pozwala przybliżyć zarysowaną powyżej wizję, sprowadza się do przekonania, że cały wszechświat - przyroda ożywiona i nieożywiona, życie wspólnotowe i indywidualne, struktury władzy i stratyfikacja społeczna, praca, religia, sztuka i rodzina stanowią wzajemnie powiązane i uporządkowane sfery podlegające niedającemu się anulować, obejść czy oszukać porządkowi. Porządek ów daje się poznać poprzez swoje liczne przejawy: cykle przyrody, stratyfikację społeczną, sztukę, architekturę, prawa, zasady, normy i tabu obowiązujące w poszczególnych dziedzinach, związane z nimi nagrody, a nade wszystko - nieuniknione kary za ich przekroczenie. Niezależnie od tego, czy idea, o której mowa, została w danej tradycji nazwana (ryta hinduizmu, dharma buddyzmu, dao taoizmu i konfucjanizmu, Asza Vahiszta zaratusztrianizmu, Maat religii egipskiej, Mądrość Boża Starego Testamentu, Moira, Dike, Temida, Erynie religii greckiej, kosmos pierwszych filozofów), pojawia się epizodycznie bez cech indywidualizujących (Sieci Szamasza z akadyjskiej opowieści o Etanie, Odwet i kierująca nim Moc Boża z egipskiego opowiadania Oko słoneczne), czy wreszcie w ogóle pozostaje bez nazwy, stanowiąc „szkielet” ogromnej liczby narracji, w których zło zostaje ukarane, a dobro nagrodzone, zawsze posiada określone własności ${ }^{16}$.

Po pierwsze, uniwersalny ład obejmuje całą rzeczywistość - jego manifestacją są nie tylko stricte moralne działania i ich konsekwencje, ale także ruchy planet, cykle przyrody, architektura, władza królewska i kapłańska, kataklizmy, nieszczęścia spotykające zarówno jednostki, jak i narody ${ }^{17}$. Ża-

${ }^{16}$ Warto zauważyć, że tego typu opowieści, znane chyba we wszystkich kulturach, nie tylko obrazują działanie kosmicznej sprawiedliwości, ale wręcz „definiują”, co jest dobre, a co złe. Słuchając takich właśnie opowieści, kolejne pokolenia uczyły się norm regulujących życie poszczególnych wspólnot. W kwestii archaiczności omawianej idei zob. B. Chmiel, Kosmos i przemoc - analiza związku kosmicznego ładu i rytów ofiarnych w perspektywie Rene Girarda, „Studia Religiologica” 48 (2015) nr 3, s. 229-244.

17 Szczególnym świadectwem takiego ładu są wypowiedzi tragicznych postaci wątpiących lub wprost negujących ów ład. Tylko w kulturze, w której idea boskiego porządku jest czymś 
den element rzeczywistości nie jest wyłączony spod sfery oddziaływania kosmicznego porządku ${ }^{18}$. Po drugie, personifikacje boskiego ładu rzadko mają charakter zindywidualizowany, a często w ogóle nie wykazują cech osobowych przysługujących innym bóstwom. Taki impersonalny charakter ma wedyjska ryta, dharma Upaniszad i dao konfucjanizmu. Podobnie w przypadku greckich Mojr, choć mówi się o ich wyrokach albo o tym, że kogoś „zabrały”, to daleko im do takich „nasyconych” cechami osobowymi bóstw, jak Zeus czy Atena. W analogicznie bezosobowy sposób przedstawiane są wszystkie wspomniane powyżej personifikacje kosmicznego porządku. Po trzecie wreszcie, bardzo często działanie i wyroki tych quasi-osobowych sił jawią się jako niemal „mechaniczne”. O ile inne bóstwa kierują się sympatiami, emocjami, kłócą się, wahają, dają przebłagać czy nawet przekupić, to w momencie gdy tekst mówi o personifikacji boskiego porządku, dane wydarzenie (najczęściej kara) dzieje się niejako automatycznie - jego nieuchronność, przypominająca nasze pojmowanie praw przyrody, jest wręcz eksponowana. To z kolei prowadzi do wniosku, że chociaż kosmiczny ład jest fundamentem myślenia moralnego, to sam nie jest „moralny”, w takim sensie, w jakim mówimy o czynach, postawach czy nawet instytucjach. Te bowiem, aby być „moralne”, muszą wykazywać osobowy charakter. Tymczasem boski porządek „dzieje” się w świecie niezależnie od tego, czy się to komuś podoba czy nie - każde działanie i zjawisko jest wplecione w jego uniwersalny mechanizm. Jest on zatem raczej „nacechowany moralnie” (w takim sensie, w jakim nacechowany moralnie jest piorun zabijający grzesznika czy rola ukrywająca skarb dla uczciwego biedaka) niż moralny.

Zarysowana powyżej, w sposób bardzo skrótowy, idea kosmicznego ładu stanowi „tło” i „szkielet” ogromnej liczby narracji religijnych, mitów, podań, baśni i legend. Każde pouczenie skierowane do niegrzecznego dziecka,

„oczywistym”, jego negacja stanowi wyzwanie i bluźnierstwo. Znakomitym przykładem takiego tekstu jest biblijna Księga Hioba. Podobny wydźwięk ma skarga Achillesa w xxıv księdze Iliady czy egipska Pieśń złamanego życiem.

${ }_{18}$ Szereg tekstów wskazuje, że nawet bóstwa podlegają jego wyrokom. Przykładowo, w Iliadzie Zeus musi pogodzić się ze śmiercią Sarpedona. Podobnie w Rygwedzie moc Mitry i Waruny - stróżów ryty - przysługuje im z jej nadania. W innych tradycjach moc personifikująca boski porządek jest hipostazą samej Istoty Najwyższej (Asza zaratusztrianizmu, starotestamentalna Mądrość Boża) i jako taka pozostaje z nią tożsama. Uniwersalność boskiego ładu wyjaśnia, dlaczego dla człowieka religijnego wszystko może być „znakiem” boskiej przychylności lub gniewu, a jednocześnie dlaczego każda niemal działalność może taki gniew wywołać. 
które skaleczyło się nożem i ma „nauczkę”, zakłada tę ideę, podobnie jak postuluje ją prawo talionu, idea dzieci cierpiących za winy ojców, miasmy, piekła, nieba, czyśćca, sansary i karmana - wszystkie te koncepcje, pomimo istotnych różnic, odwołują się do wizji nieuchronnej retrybucji, która - proporcjonalna do winy - „woła”, „,ciąży” i „czeka”, aby „spotkać” winowajcę. Jeśli przedstawiona charakterystyka jest adekwatna, to cała rzeczywistość, a nie tylko wyodrębniona sfera „sakralna”, wciela boski ład, stanowiąc tym samym jego manifestację i przestrzeń obowiązywania. Można ów ład jak i rzeczywistość określić jako naturalne, w tym sensie, że porządek leży w samej naturze rzeczywistości - każdy przedmiot $\mathrm{z}$ konieczności mu podlega i go przejawia. Przekonanie o obowiązywaniu boskiej sprawiedliwości jest tak powszechne („naturalne”), że wręcz niknie z naszej świadomości, tworząc nieuświadomioną podstawę dla całej kultury. Jednocześnie jednak, jak wspomniano powyżej, kosmiczna harmonia, nie jest kolejną „fizyczną" cechą świata, ale najgłębszą zasadą jego „dziania się”. Być może czytelnikowi, podobnie jak autorowi, narzuca się w tym momencie określenie „nadprzyrodzony”, ale jak wykazano powyżej, takie określenie może funkcjonować jedynie w opozycji do terminu „naturalny”, „przyrodzony”. Boski ład jest tymczasem zarazem taki i taki - jest najbardziej immanentną (in-natus), a zarazem transcendentną (niewyczerpującą się w żadnej konkretnej normie) zasadą wszechświata ${ }^{19}$.

Przedstawiona powyżej koncepcja nie wyklucza istnienia osób, miejsc, artefaktów i działań w wyjątkowy sposób „nasyconych” boską obecnością. Rzecz jednak w tym, że ich natura jest zintegrowana z boskim porządkiem - przekonanie o obowiązywaniu uniwersalnego ładu stanowi podstawę dla wiary w nieuchronną karę za naruszenie sfery sacrum i legitymizację obowiązku ukarania winowajcy. Co więcej, to wielkość kary stanowi jeden z czynników charakteryzujących świętą "moc” danego przedmiotu bądź zachowania. Inna jest wszak kara za złamanie przysięgi złożonej władcy,

19 Tę fundamentalną rolę widać wyraźnie w narracjach dotyczących kreacji wszechświata. W przypadku opisów, w których świat wyłania się z chaosu (symbolizowanych często jako amorficzny bezmiar wód, smok), kreacja jest „porządkowaniem” świata - nadawaniem mu formy tożsamej z ładem (opis Księgi Rodzaju, mit o Marduku i Tiamat, Hymn o Puruszy). W narracjach opisujących stworzenie jako przejście od pierwotnej jedności do wielości (głównie tradycje orientalne) stworzenie przedstawiane jest jako wyłonienie opozycyjnych sił, których nieustanna walka utrzymuje ład, a jednocześnie „popycha” świat do powrotu ku pierwotnej jedności. 
nieudzielenie pomocy swemu dobroczyńcy, inna za brak ofiary dla bóstwa, a jeszcze inna za dotknięcie świętego przedmiotu przez profana ${ }^{20}$. Jednak we wszystkich tych przypadkach charakter działania kary/nagrody jest tak samo nieuchronny, obiektywny i bezosobowy, jak w przypadku „świeckich” przewinień. Obecność i natura świętych przedmiotów, postaci i obrzędów jest zatem wpisana w „mechanizm” boskiego ładu ${ }^{21}$. Zasady „obchodzenia” się z sacrum są w ten sposób istotnym, ale nadal cząstkowym, aspektem kosmicznego porządku obejmującego wszystkie sfery bytu. Szczególnie dobitnie świadczy o tym trudność, jaką można wyczuć, śledząc relacje między kosmicznym prawem a istotami boskimi. Autorom często trudno jest wyrazić ten związek tak, aby zachować supremacje bóstw, a jednocześnie wyrazić rolę uniwersalnego prawa ${ }^{22}$. Wyroki boskiego ładu jawią się jako nadrzędne względem bogów, niezależne od ich woli, a wręcz z nią tożsame. We wszystkich tych przypadkach status kosmicznego ładu jest ontologicznie równy bogom ${ }^{23}$.

${ }^{20}$ Por. J. P. Vernant, Myth and Society in Ancient Greece, New York 1990, s. 137. Uwagi Vernanta dotyczą religii greckiej, można jej jednak odnieść do wszystkich innych tradycji.

${ }^{21}$ Oczywiście, sakralna moc danego przedmiotu, osoby czy miejsca jawi się jako pierwotna i z niej wypływa zarówno władza karania, jak i jej wysokość. Tłem dla takiego przekonania jest jednak „oczywista” idea o nieuchronnej nagrodzie/karze.

${ }^{22}$ Jednym z przejawów takiego stanu rzeczy jest trudność z przetłumaczeniem terminów denotujących kosmiczny ład. W większości przypadków nie są one tłumaczone, lecz jedynie objaśnione $\mathrm{w}$ przypisach. Wynika to $\mathrm{z}$ bardzo szerokiego pola semantycznego poszczególnych terminów. Próba oddania ich przez takie pojęcia, jak: „Ład”, „Porządek”, „Prawo” nie oddaje całej rzeczywistości, lecz jej normatywny aspekt. Co więcej, deformują rozumienie, sugerując wyłącznie „nadprzyrodzone” lub tylko „naturalne” rozumienie. Tymczasem wizja kosmicznego ładu jest zarazem deskryptywna (świat „dzieje się” według uniwersalnego porządku), jak i normatywna - stanowi podstawę zobowiązań społecznych, kultycznych, rodzinnych.

${ }^{23}$ Aby jeszcze mocniej wyakcentować ten zasadniczy aspekt relacji między kosmicznym ładem a sacrum warto odwołać się do myśli Eliadego. Pisząc o kosmizacji przestrzeni polegającej na rytualnym powtórzeniu aktu kreacji, rumuński religioznawca przeciwstawia tak uporządkowany świat chaosowi jako rzeczywistości potencjalnej, zagrażającej uporządkowanemu światu, z którą należy walczyć poprzez liturgiczne akty odtwarzające akt kreacji. Por. M. Eliade, Sacrum i profanum, Warszawa 1999, s. 23-25. W takiej perspektywie ów chaos jest przeciwieństwem ładu świata - absolutnym profanum. Pomijając już fakt, że także Zło ma swoją moc, a jego przejawy charakter hierofanii (moc zwierząt symbolizujących chaos), należy podkreślić, że w przypadku większości narracji religijnych także sfera chaosu podlega zasadom uniwersalnego porządku - wśród istot reprezentujących chaos panuje hierarchia władzy, prawa i obowiązki. Regułom podlegają również relacje między światem chaosu a „naszym” światem - istnieją metody „radzenia sobie” $\mathrm{z}$ napierającym złem, naczelną rolę pełni zasada, wedle 


\section{Desakralizacja}

Mając na uwadze powyższe analizy, można przejść do pytania o naturę desakralizacji. Jeśli pierwotne pojmowanie rzeczywistości wykracza poza rozróżnienie na sacrum i profanum, to można przyjąć, że początkiem desakralizacji będzie pojawienie się sfery profanum przeciwstawionej, na zasadzie mocnej opozycji, przestrzeni sacrum. W pierwotnej jedności wszechświata ugruntowanej w uniwersalnym porządku przenikającym całą rzeczywistość pojawia się wyłom - któraś ze sfer zaczyna jawić się jako autonomiczna względem uniwersalnego ładu. W gruncie rzeczy nie ma znaczenia, jaka sfera zaczyna być pojmowana jako świecka i w jakim stopniu jest ona „rozległa”. Istotne jest to, że uniwersalizm ładu zostaje zakwestionowany - jakiś fragment rzeczywistości przestaje być postrzegany jako „dziejący się” według obiektywnego porządku, któremu człowiek, jako jego część, musi się podporządkować. Zamiast tego zaczyna on być rozumiany jako przestrzeń swobodnej twórczości człowieka, pozbawionej boskiego wzorca i sankcji ${ }^{24}$. Oczywiście z perspektywy religijnej można tej „świeckiej” sferze przyznawać jakieś sankcje moralne i religijne, niemniej jednak związek między uniwersalnym ładem a daną rzeczywistością zostaje osłabiony - boska norma zaczyna jawić się jako zewnętrzna względem aktywności człowieka. Co więcej, stopniowo zaczyna być swoistą konkurencją dla ludzkich praw i zasad.

Powyższy proces dobrze ilustruje sytuacja w starożytnej kulturze greckiej. W epoce homeryckiej ideę nieuchronnej kary regulującej prawa i obowiązki jednostek uosabiały Mojry i Erynie ${ }^{25}$. Na kartach Iliady [Il.] natura tych

której zło zawsze zostaje ukarane. Często samo jego istnienie jest wpisane w kosmiczny proces realizacji boskiego porządku.

${ }^{24}$ Należy podkreślić, że owo „zakwestionowanie”, o którym mowa, nie musi się dokonać wprost i gwałtownie. Równie dobrze może przybrać postać powolnych zmian w kulturze, które doprowadzają w pewnym momencie do „zauważenia” profanum.

${ }^{25}$ „Mojra była, co prawda, siłą moralną, ale nie można sądzić, że wyłącznie dobroczynną lub, że miała jakikolwiek wzgląd na ograniczone korzyści i pragnienia ludzkości. Co więcej, i jest to najważniejsza uwaga, nie była ona obdarzona zdolnością przewidywania, celowością, planem - te bowiem są dziedziną ludzi i spersonalizowanych bogów. Mojra jest ślepą, automatyczną siłą, pozwalającą na swobodną grę podporządkowanym jej celom i pragnieniom bogów i ludzi w obrębie wyznaczonych sfer, ale uderza z nieuchronną zemstą w momencie gdy przekraczają jej granice" (F. Cornford, From Religion to Philosophy. A Study in the Origins of Western Speculation, New York 1957, s. 20-21). Polemikę z poglądami Cornforda można znaleźć 
bardzo słabo spersonalizowanych bóstw przypomina naturę Trwogi (Dejmós), Zgrozy (Fóbos) i Niezgody (Éris) - gwałtownych sił uderzających na ludzi w niespodziewanym momencie. Podobnie jak one, Mojra dosięga wojowników (Il. xVI, 334), wszystko zwycięża (Il. xIX, 410), odpowiada za ludzkie decyzje (Il. v, 614), jej wyroków nie można zmienić (Il. vi, 488). Erynie strzegą obowiązków wynikających ze złożonej przysięgi (Il. xıx, 259), relacji rodzinnych (Il. Xv, 204). Działanie tych sił jest gwałtowne i nieuchronne, nawet sam Zeus nie może ich zmienić (Il. XVI, 435-445) ${ }^{26}$. Już w epoce homeryckiej można znaleźć antycypacje późniejszego poglądu o zaślepieniu (ate) jako boskiej karze za pychę (hybris) wynikającej z przekroczenia właściwej człowiekowi granicy (Il. XI, 512). Zachowania mieszczące się w granicach właściwych danemu człowiekowi wynikały z jego pozycji społecznej i rodzinnej, zobowiązań, jakie wziął na siebie względem bogów i ludzi, a także faktu, że jest tylko człowiekiem. Mojry i Erynie, strzegąc tego porządku, pojawiają się w momentach, w których trzeba podkreślić nieuchronność, srogość oraz bezwzględność zarówno samych zasad, jak i związanych z nimi kar²7.

Terminem, który w epoce pierwszych filozofów zyskał szczególną funkcję jako określenie uniwersalnego porządku, był kosmos. Termin ten pierwotnie oznaczał właściwe zachowanie, przestrzeganie porządku i zasad życia społecznego, później odniesiony został (ok. v w. p.n.e.) do całej rzeczywistości jako uporządkowanej wewnętrzną normą. W takim też sensie był używany przez pitagorejczyków, a wcześniej przez Heraklita ${ }^{28}$. Analizując myśl presokratyków, można dostrzec, że nie tylko pojęcie kosmosu odnosiło się do idei uniwersalnego ładu. Podobną funkcje pełnił apeiron Anaksymandra, który wszytko „obejmuje wszystko i wszystkim rządzi”, w świecie, w którym rzeczy niszczeją i powstają „zgodnie z koniecznością; płacą bowiem sobie nawzajem karę i pokutę za niesprawiedliwość, zgodnie z postanowieniem

w pierwszych dwóch rozdziałach pracy E. R. Doddsa, Grecy i irracjonalność, przeł. J. Partyka, Kraków 2014. Analizując rolę Mojry w epoce homeryckiej, warto uwzględnić książkę A. Krokiewicza, Moralność Homera i etyka Hezjoda, Warszawa 1959.

${ }^{26}$ Por. J. P. Vernant, Myth and Society in Ancient Greece, s. 107-108.

${ }^{27}$ Dobrym omówieniem natury i funkcji Mojry jest wspomniana powyżej książka A. Krokiewicza, a zwłaszcza jej III rozdział.

${ }^{28}$ Por. G. S. Kirk, J. E. Raven, M. Schofield, Filozofia przedsokratejska, przeł. J. Lang, Warszawa 1999, s. 164-165. 
Czasu”29. Dla Heraklita, zajętego problemem harmonii i ładu wszechświata, immanentną zasadą porządku był z kolei boski Logos działający poprzez nieustanne równoważenie napięć między przeciwieństwami. „Umysł” (nous) Anaksagorasa, „miłość” (philia) i „waśń” (neikos) Empedoklesa, logos stoików, a wreszcie „natura” Arystotelesa - wszystkie te pojęcia denotują źródło i zasadę kosmicznego ładu, którego człowiek jest częścią i który winien rozpoznać, a następnie realizować we właściwy sobie sposób ${ }^{30}$. Hierarchiczna struktura społeczeństwa i związany z nią podział praw i obowiązków stanowiły jeden z głównych przejawów kosmicznego ładu.

Zarysowany powyżej sposób pojmowania rzeczywistości reprezentuje wizję świata, w której podział na sacrum i profanum nie występuje na zasadzie wzajemnie wykluczającej się opozycji - całą rzeczywistość jednoczy boski ład przejawiający się w hierarchii społecznej i prawie (nomos) ${ }^{31}$. Takie przeciwstawienie pojawia się jednak już sofistów, a mianowicie w poglądzie Hippiasza o różnicy między naturą (physis) a prawem (nomos). Na naturę składało się to, co wspólne dla wszystkich ludzi i powszechnie obowiązujące. Prawa organizujące życie społeczne i indywidualne miały być wytworem człowieka - zmiennymi i względnymi zasadami różnicującymi ludzi na zasadzie konwencji, służąc w ten sposób wybranym grupom i jednostkom. W ten sposób cały porządek prawny przestał stanowić domenę kosmicznego ładu, co z kolei można rozumieć jako wytworzenie sfery profanum - dziedziny zależnej tylko od ludzkich decyzji. Taki punkt widzenia stał się podstawą do optymistycznego pojmowania dziejów, a zwłaszcza doniosłej roli ówczesnej epoki ${ }^{32}$. Skoro człowiek i tylko on jest odpowiedzialny za kształt prawa, to błędy przeszłych pokoleń mogą zostać naprawione - można wykształcić nowego człowieka i stworzyć nowy porządek społeczny oparty już nie na pozornie boskim prawodawstwie, ale na adekwatnym odczytaniu

${ }^{29}$ W kwestii natury kosmicznego ładu u Anaksymandra por. G. S. Kirk, J. E. Raven, M. Schofield, Filozofia przedsokratejska, s. 124-124; W. Jaeger, Teologia wczesnych filozofów greckich, przeł. J. Wocial, Kraków 2007, s. 78-79; W. Jaeger, Paidea, przeł. M. Plezia, Warszawa 1962, s. 137-138.

3o Z tego też względu wszystkie przywołane pojęcia mają szczególny normatywno-deskryptywny charakter. Wskazują zasadę ładu, a jednocześnie fundament moralności. Znakomite wprowadzenie do poglądów greckich myślicieli na temat kosmicznego porządku stanowi książka A. Drozdka, Greccy filozofowie jako teolodzy, Warszawa 2011.

${ }^{31}$ Por. D. Dembińska-Siury, Człowiek odkrywa człowieka, Warszawa 1991, s. 91-92.

${ }^{32}$ Por. E. R. Dodds, Grecy i irracjonalność, s. 148. 
uniwersalnej ludzkiej natury. W takiej perspektywie właściwego znaczenia nabierają sztandarowe hasła sofistów głoszące możliwość „nauczenia się” cnoty oraz mówiące o roli człowieka jako miary wszechrzeczy.

Cnoty można się nauczyć, gdyż nie jest ona darem bogów - zdaniem Protagorasa Zeus nie daje ludziom gotowych praw, lecz jedynie wszczepia naturalne inklinacje oraz poczucie ładu i sprawiedliwości leżące u podstaw życia społecznego ${ }^{33}$. Organizacja społeczna oraz związany z nią podział praw i obowiązków nie są zatem boskim ładem, który należy zachowywać, pielęgnować i przekazywać, lecz jedynie historycznym wytworem człowieka. Przyjęcie takiej perspektywy stanowiło podstawę do szeroko zakrojonych reform - racjonalnego urządzenia stosunków społecznych już nie w formie aktualizacji mitycznych narracji, ale w oparciu o rozumowe odczytanie ludzkiej natury.

Zjawisko desakralizacji, które - w przypadku uznania dotychczasowych rozważań - ma swój początek w poglądach sofistów, można poddać analizie z jeszcze jednej perspektywy, w której rola Protagorasa i jego następców również stanowi punkt wyjścia ${ }^{34}$. Chodzi mianowicie o przyczynę wytworzenia takiej profańskiej perspektywy. Jeśli powrócimy do „klasycznego” światopoglądu religijnego, zauważymy, że człowiek funkcjonuje w nim jako część większej struktury regulowanej prawami uniwersalnego ładu. Rola, jaką pełni, oraz związane z nią obowiązki jawią się jako nadane „z góry”, czego świadectwem jest powszechność narracji o boskim pochodzeniu władzy, stratyfikacji społecznej, praw i obyczajów. Jednocześnie nośnikiem

33 Por. W. Jaeger, Paideia, s. 315.

${ }^{34}$ Pogląd dopatrujący się początków desakralizacji w poglądach sofistów może jawić się jako zbyt kategoryczny, zwłaszcza że antycypację ich poglądów na różnicę między absolutną naturą a względnym zwyczajem stanowią już poglądy Ksenofanesa. Por. D. Dembińska-Siury, Człowiek odkrywa człowieka, s. 116-117, G. S. Kirk, J. E. Raven, M. Schofield, Filozofia przedsokratejska, s. 174. Co więcej, czynników sprzyjających pojawieniu się nowych poglądów na naturę porządku społecznego można doszukiwać się już we wcześniejszych procesach społeczno-kulturowych. Por. J. P. Vernant, Źródła myśli greckiej, przeł. J. Szacki, Gdańsk 1996, s. 66, a nawet w spisaniu narracji mitycznych. Por. J. P. Vernant, Myth and Society in Ancient Greece, s. 203-205. Z pozycji tradycjonalizmu integralnego związek pomiędzy użyciem pisma a desakralizacją analizuje A. K. Coomaraswamy, The Bugbear of Literacy, w: The Essential Ananda K. Coomaraswamy, ed. R. P. Coomaraswamy, Bloomington 2004, s. 53-66. Rzecz jednak w tym, że poglądy sofistów wydają się być pierwszym tak zdecydowanym i jednoznacznym przeciwstawieniem kultury i natury oraz dostrzeżeniem w tej pierwszej sferze tworu wyłącznie ludzkiego, powiązanego z akceptacją wszystkich konsekwencji tego stanowiska. 
i przejawem porządku jest cała rzeczywistość społeczna i przyrodnicza - ład nie jest pojmowany jako coś zewnętrznego względem tożsamości jednostki, ale jest podstawą dla jej samookreślenia - immanentnym aspektem formującym samoświadomość poszczególnych jednostek. Idea boskiego ładu funkcjonuje niczym okulary, poprzez które człowiek rozumie nie tylko losy świata, ale nade wszytko samego siebie i swoją aktywność. Dzięki temu idee kosmicznego porządku znajdują swój wyraz w sztuce, architekturze, poezji, zwyczajach - każdy ludzki twór nosi znamię tego ładu i jest weń wpisany. Co istotne, możliwość rozpoznania praw rządzących światem pozwala się do nich dostosować i wykorzystać ich bezwzględny charakter ${ }^{35}$. Niezależnie jednak od konkretnych wyborów człowiek cały czas pozostaje w tym uniwersalnym „mechanizmie” - tkwi w nim tak głęboko, że przestaje go zauważać, ład staje się tak oczywisty, że uświadamiany dopiero wtedy, gdy „nie działa” (Księga Hioba, skarga Achillesa skierowana do Priama, przykłady poematów greckich i egipskich, w których zwątpienie w boski ład idzie w parze z zachętami do „używania życia”) lub nastręcza wyjątkowych trudności (Bhagawadgita) i trzeba ten pozorny brak porządku wytłumaczyćc ${ }^{36}$.

Tymczasem dla sofistów to człowiek staje się miarą wszechrzeczy; co więcej nie chodzi tutaj o konkretnego człowieka, którego miejsce w społeczeństwie wyznacza uniwersalny ład, a więc uposażonego w określone prawa, obowiązki i sankcje, ale „czystego” - takiego, jakim jest bez wpływu kultury. To właśnie w oparciu o tak pojętą ideę ludzkiej natury trzeba, poprzez wychowanie, stworzyć dobrego obywatela i prawe społeczeństwo. Tutaj twórcą

35 Tutaj, w moim przekonaniu, bije źródło wszelkich ekspiacji uprzedzających nieuchronną karę oraz dobrych czynów, które „muszą” być nagrodzone. Co więcej, idea kosmicznego porządku stanowi światopoglądowe tło dla wszelkich wróżb, znaków i przepowiedni. Każde wydarzenie jawi się bowiem jako włączone w boski ład, który można odczytać i zrozumieć, co daje asumpt dla przewidywania przyszłości.

${ }^{36}$ Świadomość uniwersalnego ładu nie jest efektem nagromadzonych doświadczeń poszczególnych „sprawiedliwych” wydarzeń. Obserwacja świata skłania raczej do przekonania, że żyjemy w okresie wyjątkowego chaosu (odzwierciedla to występująca w wielu kulturach idea degeneracji wszechświata). Jest wręcz odwrotnie, to idea kosmicznego porządku tworzy, niczym katowskie kategorie a priori, treść doświadczenia i pozwala je rozumieć jako dobre/ złe, sprawiedliwe/niesprawiedliwe, a sam świat jako rozwijający się lub degenerujący. Uniwersalność ładu przejawia się m.in. w tym, że zawsze gdy mowa o degeneracji moralnej (biblijny upadek pierwszych ludzi, kalijuga tradycji wedyjskiej, wiek żelazny Hezjoda, skażenie dobrych tworów Ahura Mazdy przez Angra Mainyu), idzie ona w parze z biologiczną, poznawczą i społeczną. 
jest już sam człowiek, który nie odtwarza boskich wzorców, ale projektuje swój porządek w oparciu o racjonalny namysł nad rzeczywistością. W konsekwencji świat przestaje się jawić jako uporządkowana struktura, której człowiek jest częścią, ale jako obdarzony specyfiką i potencjałem materiał, z którego ludzkość tworzy „swój” świat wedle własnej miary. W schemacie tradycyjnym człowiek jest częścią przenikniętego boskim porządkiem universum, dla sofistów świat specyficznie ludzki to przestrzeń profanum wytworzona przez ludzi i uporządkowana mocą ich rozumu. Ujmując rzecz nico inaczej, można stwierdzić, że desakralizacja wynika nie tyle ze zmiany ontologicznej polegającej na wytworzeniu określonej sfery „świeckiej”, ile ze zmiany sposobu widzenia świata. Taka aktywność jest bowiem drugorzędna i stanowi konsekwencję znacznie głębszej transformacji - pojawienia się „profańskiej” świadomości, w której człowiek jawi się samemu sobie jako autonomiczny względem Boga i Jego planów ${ }^{37}$. W sferze tej autonomii to człowiek jest centrum i źródłem, nawet jeśli „jego” porządek zgadza się $\mathrm{z}$ boskim.

Myśl sofistów nie tylko wyznacza początek desakralizacji, ale również ukazuje jej źródło, którym jest antropocentryzm. Jeśli w dowolnej sferze uzna się człowieka nie za element obiektywnego porządku (do którego musi się dostosować, respektując obiektywne normy), ale za twórcę, który - kierując się własną wolą, rozumem, dobrem ogółu, miłosierdziem czy czymkolwiek innym, ale nie boskim wzorcem - tworzy daną rzeczywistość, to nawet jeśli ów twór będzie z perspektywy religijnej oceniany jako dobry, słuszny „kompatybilny” z religią, to i tak pozostanie ludzki - profański. Profanum pojawiło się, gdy człowiek uznał, że jego zadaniem jest nie tyle odtwarzać i realizować obiektywny porządek działający w całej rzeczywistości, ile tworzyć i ustanawiać swoje prawo i oparty na nim ludzki ład ${ }^{38}$. Kwestia

37 Por. R. Guénon, The Crisis of Modern World, transl. M. Pallis, A. Osborne, R. C. Nicholson, Hillsdale 2004, s. 53.

${ }^{38} \mathrm{~W}$ perspektywie teologicznej narzuca się tutaj odniesienie do pierwszych rozdziałów Księgi Wyjścia i buntu pierwszych ludzi, którzy sami chcieli decydować o dobru i złu. W kulturze greckiej źródła nieuchronnej kary upatruje się w przekroczeniu właściwej człowiekowi granicy, miary decydującej o jego miejscu w świecie, co powoduje pychę (hybris) i uruchamia działanie sprawiedliwości (dike). Coomaraswamy upatruje wspólnego źródła zwrotu „czynić coś na sposób heretycki” z terminem „wybierać według swego uznania”. Por. A Figure of Speech or a Figure of Thought, w: The Essential Ananda K. Coomaraswamy, s. 38. We wszystkich tych przypadkach źródłem zła jest zastąpienie boskiej „woli”/obiektywnego ładu wolą człowieka. 
relacji tych ludzkich tworów względem wyodrębnionej w taki negatywny sposób rzeczywistości stricte boskiej jest w gruncie rzeczy drugorzędna człowiek ma „swój” świat, do którego boskość może wpuszczać dobrowolnie lub ulegać jej pod przymusem, w każdym jednak przypadku jest ona czymś „zewnętrznym” względem tej ludzkiej sfery.

Powyższe dociekania mogą wydawać się nieco ogólnikowe i słabo uzasadnione. $Z$ tego względu warto przytoczyć jeszcze jeden przykład, który nie tylko potwierdzi wnioski płynące $\mathrm{z}$ dotychczasowych analiz, ale także unaoczni subtelny charakter samego zjawiska desakralizacji. Wracając do wspomnianej powyżej kultury renesansowej, można zauważyć, że jednym z przejawów nowej perspektywy była rosnąca popularność idei filozofii wieczystej (philosophia perennis). Przywołane określenie, autorstwa włoskiego biskupa i kontrreformatora Aggostina Steuca, denotuje postawę właściwą dla szerokiego grona włoskich intelektualistów (takich jak: Marsilio Ficino, Giovanni Pico della Mirandola, Mikołaj z Kuzy), której fundamentem było przekonanie, że - pomimo szeregu różnic dzielących poszczególne religie i systemy filozoficzne - wszystkie one, właściwie zrozumiane, przekazują tę samą odwieczną i boską Prawdę. Wykazanie postulowanej jedności systemów filozoficznych i doktryn religijnych miało dokonać się poprzez wydobycie ukrytej w poszczególnych tradycjach uniwersalnej treści. Jej poszukiwania stanowiły jeden z głównych motywów twórczości renesansowej.

Przykładem takiego opracowanie jest dzieło Mikołaja z Kuzy De pace fidei, w którym nie tylko głosi on, że istnieje jeden Bóg nazywany i czczony na różne sposoby przez poszczególne religie, ale także przedstawia program stworzenia jednej światowej religii (z jedną doktryną i wielością rytów) ze stolicą w Jerozolimie ${ }^{39}$. Treść oraz pluralizm kultu charakterystyczny dla tej nowej „religii” są w tym momencie drugorzędne. Istotny jest natomiast fakt, że praca Kuzańczyka jest świadectwem - rodzącego się wówczas, a traktowanego dzisiaj wręcz jako oczywistość - przekonania, że religią, jako sferą sacrum, można manipulować - wydobywać święty „sens” Objawienia, zmieniać względną „formę”, „dostosowywać” i „aktualizować” przekaz. Cały dialog między Słowem (zastąpionym później przez św. Piotra) reprezentującym Boga a przedstawicielami poszczególnych religii, kultur i nacji sprowadza się do wyodrębnienia uniwersalnej doktryny, sakramen-

39 Por. Nicolas of Cusa, De Pace Fidei and Cribratio Alkorani. Translation and Analysis, ed. J. Hopkins, Minneapolis 1994, s. 637, 670. 
tów, na które wszyscy się zgadzają i pozostawienia przestrzeni dla swobody lokalnego kultu ${ }^{40}$. Taka postawa stoi w sprzeczności $\mathrm{z}$ dotychczasowym myśleniem, w którym święte teksty na równi $\mathrm{z}$ organizacją, obrzędami i rytuałami traktowane były jako nadane przez Boga, tworzące Tradycję i tożsamość wspólnot i jako takie nienaruszalne ${ }^{41}$. Tymczasem od epoki renesansu to człowiek zaczyna decydować o absolutnej „treści” i względnej „formie” religii - o tym, co należy do poszczególnych sfer zaliczyć i jak się z nimi obchodzić. Porządek teologiczny przejawiający się w doktrynie, organizacji, liturgii i moralności zaczyna być świadomie kształtowany przez człowieka i identyfikowany z jego aktywnością. Tym samym, paradoksalnie, renesansowe poszukiwanie „autentycznego”, „czystego” chrześcijaństwa ujawniło swoje prawdziwe oblicze - poza sferą polityki również teologia została poddana wpływom antropocentryzmu idącego $\mathrm{w}$ parze $\mathrm{z}$ desakralizacją. Cały porządek religijny, poza mętną ideą boskiego „sensu” (który trzeba dopiero ustalić), zaczyna się jawić jako twór ludzki, historycznie zmienny, pozbawiony boskiego autorytetu, którego dyspozytorem był do tej pory Kościół katolicki ${ }^{42}$. To z kolei decyduje o drugorzędnym znaczeniu wszelkich instytucji, form i norm prawnych. Przestrzeń, której organizacja i regulujące ją zasady należą do porządku ludzkiego, zaczyna w epoce renesansu zataczać coraz szersze kręgi, zostawiając coraz mniej miejsca dla „odkrytej” w owym czasie sfery sacrum.

\section{Bibliografia}

Biliński K., Refleksje o podstawach ruchów neopogańskich, „Państwo i Społeczeństwo" 8 (2008) nr 4, s. 55-65.

Chmiel B., Kosmos i przemoc - analiza związku kosmicznego ładu i rytów ofiarnych w perspektywie Rene Girarda, „Studia Religiologica” 48 (2015) nr 3, s. 229-244.

${ }^{40}$ Por. Nicolas of Cusa, De Pace Fidei..., s. 669.

${ }^{41}$ Oznaką takiego myślenia jest głęboko zakorzeniona niechęć do jakichkolwiek zmian w świętych tekstach, języku i obrzędach liturgicznych czy formach życia uznawanych za istotne dla tożsamości danej religii. Współcześnie ta postawa przejawia się wśród neofitów, którzy często przejmują nie tylko najważniejsze elementy nowej religii, ale również te uznawane za drugorzędne i nieistotne.

${ }^{42}$ Por. R. Guénon, The Crisis of Modern World, s. 15-17. 
Coomaraswamy A. K., The Bugbear of Literacy, w: The Essential Ananda K. Coomaraswamy, ed. R. P. Coomaraswamy, Bloomington 2004.

Cornford F., From Religion to Philosophy. A Study in the Origins of Western Speculation, New York 1957.

Dembińska-Siury D., Człowiek odkrywa człowieka, Warszawa 1991.

Dodds E. R., Grecy i irracjonalność, przeł. J. Partyka, Kraków 2014.

Eliade M., Sacrum i profanum, Warszawa 1999.

Eliade M., Szamanizm i archaiczne techniki ekstazy, przeł. K. Kocjan, Warszawa 2011. Eliade M., Traktat o historii religii, przeł. J. Wierusz-Kowalski, Warszawa 1966.

Gilson E., Jedność doświadczenia filozoficznego, Warszawa 1968.

Guénon R., The Crisis of Modern World, transl. M. Pallis, A. Osborne, R. C. Nicholson, Hillsdale 2004.

Jaeger W., Paidea, przeł. M. Plezia, Warszawa 1962.

Jaeger W., Teologia wczesnych filozofów greckich, przeł. J. Wocial, Kraków 2007.

Kirk G. S., Raven J. E., Schofield M., Filozofia przedsokratejska, przeł. J. Lang, Warszawa 1999.

Krokiewicza A., Moralność Homera i etyka Hezjoda, Warszawa 1959.

Nicolas of Cusa, De Pace Fidei and Cribratio Alkorani. Translation and Analysis, ed. J. Hopkins, Minneapolis 1994.

Otto R., Świętość. Elementy irracjonalne w pojęciu bóstwa i ich stosunek do elementów racjonalnych, przeł. B. Kupis, Warszawa 1999.

Swieżawski S., Eklezjologia późnośredniowieczna na rozdrożu, Kraków 1990.

Vernant J. P., Myth and Society in Ancient Greece, New York 1990.

Vernant J. P., Źródła myśli greckiej, przeł. J. Szacki, Gdańsk 1996.

\section{Streszczenie}

Celem niniejszego artykułu było wskazanie zasadniczych elementów składających się na proces desakralizacji kultury Zachodu. W pierwszej części przedstawiono zasadnicze elementy charakteryzujące „tradycyjne” pojmowanie kultury, którego wyróżnikiem był brak ostrego rozróżnienia na sferę sacrum i profanum ugruntowany w idei kosmicznego ładu. Druga część dotyczy genezy desakralizacji, którą - w przypadku kultury zachodniej - należy wiązać najpierw z myślą sofistów, a następnie $\mathrm{z}$ ideami renesansu. $\mathrm{W}$ obu przypadkach desakralizacja wiąże się $\mathrm{z}$ antropocentryzmem. Istotą antropocentryzmu jest takie postrzeganie rzeczywistości, w którym człowiek pojmuje samego siebie nie jako integralną część boskiego ładu, 
który winien rozpoznać i realizować we właściwy sobie sposób, ale jako autonomicznego twórcę kreującego „swój” świat wedle własnych praw. Kwestia, czy owe ludzkie prawa są zgodne z boskim porządkiem, czy pozostają z nim w sprzeczności jawi się tym samym jako drugorzędna - tym, co zasadnicze, jest geneza i natura ładu panującego w świecie człowieka.

\section{Słowa kluczowe}

sacrum, profanum, desakralizacja, filozofia wieczysta

\section{Summary}

\section{Decline of the Sacredness - Nature and Sources of Desacralisation of West- ern World}

The aim of this article was to indicate the essential elements of the process of desacralization of Western culture. In the first part, I individuated fundamental elements characterizing the "traditional" concept of culture, whose main feature was the lack of a sharp distinction between the realm of the sacred and the profane grounded in the idea of cosmic order. The second part concerns the genesis of desacralization, which - in the case Western culture - is associated with the idea of the sophists' concepts and ideas of the Renaissance. In both cases, desacralization is associated with anthropocentrism. The essence of anthropocentrism is the perception of reality, in which man perceives himself not as an integral part of the divine order, which he should recognize and accomplish in the right way, but as an autonomous creator, directing the world according to his own laws. The question whether these human laws are in harmony with the divine order or remain in contradiction with it appears to be secondary - essential is genesis and nature of order in the human world.

\section{Keywords}

sacrum, profanum, desacralisation, perennial philosophy 